\title{
Review: Floral resources diversity and vegetation types important for honeybees in Ethiopia
}

\author{
ADMASSU ADDI, TURA BAREKE \\ Oromia Agricultural Research Institute, Holeta Bee Research Center. P.O. Box 31, West Showa Zone, Oromia Region, Ethiopia. \\ Tel.: +251-112370376, +251-112370006, Fax.: +251-112370377, "email: admassuaddi@gmail.com, "v trbareke@gmail.com
}

Manuscript received: 2 August 2019. Revision accepted: 12 September 2019.

\begin{abstract}
Addi A, Bareke T. 2019. Review: Floral resources diversity and vegetation types important for honeybees in Ethiopia. Asian J For 3: 64-68. The high biodiversity of Ethiopia is attributed to its wide range of altitude and great geo-morphological diversity. This has resulted in the existence of a high diversity of floral resources of which majority of them are visited by honeybees. This paper aimed to review existing studies on bee floral resources in Ethiopia to understand the types of bee plants, floral diversity, flowering period and food source offered by the plants. Over 1500 species of indigenous and exotic plants belonging to 105 bee plant families have been identified. The growth form of bee forage comprises $41.6 \%$ herb, $28.7 \%$ shrubs, $21.7 \%$ trees, and $8 \%$ climbers. The majority of bee plant species flower from September to November and April to May, resulting in two major honey flow periods in the country. From this information, Ethiopia has rich bee forage diversity across different vegetation types, however, further collection and documentation of bee flora are required in unaddressed areas of the country. Thus in situ conservation by ecological restoration, and raising and planting of seedlings of bee forages should be promoted for sustainable honey production.
\end{abstract}

Keywords: Bee forages, honeybee, honey flow, pollen

\section{INTRODUCTION}

Ethiopia is one of the countries in the world endowed with rich biodiversity, including its natural vegetation. Natural vegetation in Ethiopia can be classified into 13 vegetation types (Friis et al. 2012), namely: (i) Desert Vegetation, (ii) Semi-Desert Scrub, (iii) AcaciaCommiphora Bushland and Thicket, (iv) AcaciaCommiphora Narrow-leaved Deciduous Woodland and Forest, (v) Dry Evergreen Montane Forest, (vi) Afro-alpine and Sub-Afro alpine vegetation, (vii) Moist Evergreen Montane Forest, (viii) Transitional rainforest, (ix) Combretum-Terminalia, (x) Broad-leaved Deciduous Woodland and Forest, (xi) Fresh-water lakes and open water vegetation, (xii) freshwater marshes and swamps flood plain, and (xiii) Lakeshore vegetation. These vegetation types are found in different climatic regions, comprising different flora. In total, there are 6000 species of flowering plants recorded to be found in Ethiopia, most of them are bee plants that have apicultural importance (Admassu et al. 2014a; Ensermu and Sebsebew 2014).

Each vegetation type in Ethiopia comprises different plant species associated with particular bee species, as such each vegetation type is not of equal importance for honey production due to suitability of climate, availability of food source to Apis mellifera subspecies and other environmental factors (Tura and Admassu 2018). The large variety of floral vegetation types in Ethiopia results in the existence of higher population density of honeybees and makes the country one of the 10 largest honey producers and the $3^{\text {rd }}$ largest beeswax producer's worldwide (Fitchl and Admassu 1994; Gidey and Mekonen 2010; USAID 2012). The estimated honey production potential of the country is 500,000 metric tons per annum and Apis mellifera also contributes to pollination of plants for crop production and biodiversity conservation.

However, there is decreasing trend of honey production in Ethiopia with annual honey production is recently only 54,000 metric tons and 5000 tons of beeswax (CSA 2017). In view of this problem, the major aim of this paper is to study the important findings that have been achieved during the last two decades in area of bee forage research. In this review, identification, distribution, and diversity of bee resources, preparation of flowering calendar, characterization, and evaluations of herbaceous, shrubs, and tree plants, and the role honeybees in natural resource conservation and agroforestry systems are discussed.

\section{IMPORTANT VEGETATION TYPES IN ETHIOPIA FOR BEEKEEPING}

The vegetation types and associated bee flora of Ethiopia are presented in Table 1. Based on the table, desert and semi-desert vegetations are characterized by highly drought-tolerant species but limited contribution for beekeeping due to erratic rainfall and extreme drought. However, Acacia-Commiphora, bushland, and thickets are important for beekeeping production which is predominately found escarpment of Afar, Oromia, Amhara 
and SNNP, and Somalia regional state (Admassu et al 2014a). This area is highly vulnerable to crop production due to the moisture deficit and recurrent drought, as such beekeeping is alternative livelihood option.

The central and mountainous chains and some parts of eastern and northern Ethiopia are covered by Dry Evergreen Montane vegetation. This vegetation type represents a complex system of successions involving extensive grasslands rich in legumes. Ethiopian agriculture is developed in these areas for thousands of years (Zerihun 2012). The intensive utilization of the areas for agriculture has resulted in loss of forests and it has been replaced by bushland and weeds. The vegetation is relatively suitable for apiculture due to availability of both natural plant species and cultivated crops such as oil crops, cereals, pulses and horticultural crops. Currently, this area faces bee forage scarcity due to high human population and livestock pressure and also intensive application of pesticides for crop agriculture (Admassu et al. 2014a).

Afroalpine, particularly Ericaceous belt, is physiognomically characterized by the dominance of shrubs such as Erica arborea. The Erica arborea honey is well known in this vegetation but the area is affected by overgrazing and massive soil erosion. The E. arborea honey is commonly found in Wochi district in West Shoa zone of Oromia regional states Gemechis 2014).

The moist evergreen Afromontane forest occurs mainly in the southwestern part of the Ethiopian highlands. The Afromontane rainforests in southwestern Ethiopia are one of potential areas for commercial and small-scale beekeeping production due to a great density of vegetation cover and high honeybee population. Beekeeping activity is a major source of income for the community surrounding the forest and contributes to up to $95 \%$ of a household's annual cash income including for payment of government tax, clothing, and for school fees (Paulos 2011).

The Combretum-Terminalia Broad-leaved Deciduous Woodland and Semi-evergreen low land Forest are found in Gambella, Beneshangul Gumuz Region, and along the Tekeze River basin in Tigray and Amhara regional states. In this forest, Manilkara butugi and Terminalia brownii honey types are well known from Gambella region
(Tura 2018) and Sheko district in Bench-Maji zone of Southern Nations and Nationalities. Moreover, Ziziphusspina christi honey is also reported from North West of Gondar in Amhara regional state along the Sudanese border (Zewdu et al. 2016).

\section{BEE FLORA SPECIES DIVERSITY IN ETHIOPIA}

In apiculture, identification and documentation of nectar and pollen source plants are the most limiting factors for honey production (Tura and Admassu 2018). In this regard, Holeta Bee Research Center has identified and characterized bee forages grown at different climatic regions of the country. Accordingly, more than 1500 bee plant species are identified, belonging to 670 genera, and 105 families, accounting $10 \%$ of the total flora of Ethiopia and Eritrea of which 310, 440 and 750 species of trees, shrubs and herbs respectively (Fitchl and Admassu 1994; Admassu et al. 2014a; Tura and Admassu 2018a) (Figure 1).

Among the identified plant families, Asteraceae, Acanthaceae, Fabaceae, Rubiaceae, Poaceae, Lamiaceae, and Euphorbiaceae are the most frequent families, represented by the highest number of bee forage species (Figure 2). The Asteraceae becomes one of the dominant families in angiosperm phylogeny due to mode of pollination, seed dispersal and adaption to different ecological niches. Moreover, this family has attractive flower color which enables the plant to be pollinated by different insect pollinators including honeybees, favoring them to colonize wide ecological ranges for honey production (Tura et al. 2014; Tura and Admassu 2018a).

Regarding the distribution of plants, the highest number of species has been collected from Oromia, Southern Nations and Nationalities People region, Amhara, Tigray and Gambella and no collection has been made from Somali and Afar regional states (Figure 3). It shows that there is a need for further extensive bee forage collection and documentation from Northern Ethiopia and remote areas of Oromia, Somali, Afar and Beneshangul Gumuz regional states.

Table 1. Major vegetation categories of Ethiopia with bee flora species

\begin{tabular}{|c|c|c|}
\hline Vegetation types & $\begin{array}{l}\text { Altitudinal } \\
\text { range (m) }\end{array}$ & Major bee flora \\
\hline $\begin{array}{l}\text { Acacia-Commiphora bushland and } \\
\text { thickets }\end{array}$ & $400-1800$ & $\begin{array}{l}\text { Hypoestes forskaolii, Aloe spp., Acacia tortolis, Acacia senegal and Acacia } \\
\text { brevispica }\end{array}$ \\
\hline Dry Evergreen Montane vegetation & $1800-3000$ & $\begin{array}{l}\text { Olea europaea subsp.cuspidata, Eucalyptus globulus, Trifolium spp., Becium } \\
\text { grandiflorum, Hypericum revolutum, and Guizotia scabra }\end{array}$ \\
\hline Afro alpine and Ericaceous belt & $3000-3200$ & $\begin{array}{l}\text { Erica arborea, Hypericum revolutum, Geranium arabicum, Helichrysum } \\
\text { citrispinum, and Anthemis tigreensis }\end{array}$ \\
\hline Moist evergreen Afromontane forest & $1500-2600$ & $\begin{array}{l}\text { Schefflera abyssinica, Croton macrostachyus, Coffea arabica and Vernonia } \\
\text { amygdalina }\end{array}$ \\
\hline Transitional rain forest & $1000-1900$ & Coffea arabica, Pouteria analifolia, Manikila butji \\
\hline Combretum terminalia Broad forest & $400-600$ & $\begin{array}{l}\text { Manilkarabutugi, Terminalia brownii, Combretum molle, Grewia bicolor, } \\
\text { Anogeissus leiocarpa, Acacia tortolis, Hypoestes forskaolii, and Ziziphus spina- } \\
\text { christi }\end{array}$ \\
\hline
\end{tabular}

Note: Admassu et al. (2014a); Tura et al. (2014); Tura et al. (2017); Tura and Admassu (2018) 


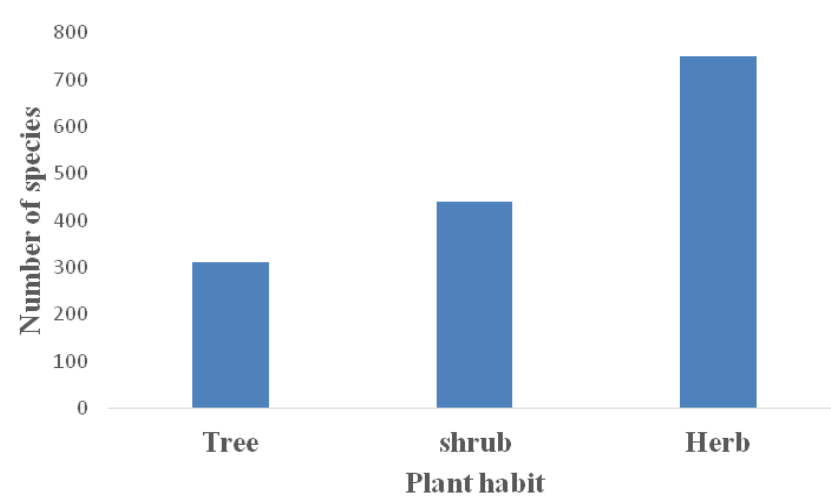

Figure 1. The habit of bee plant species identified from different parts of Ethiopia

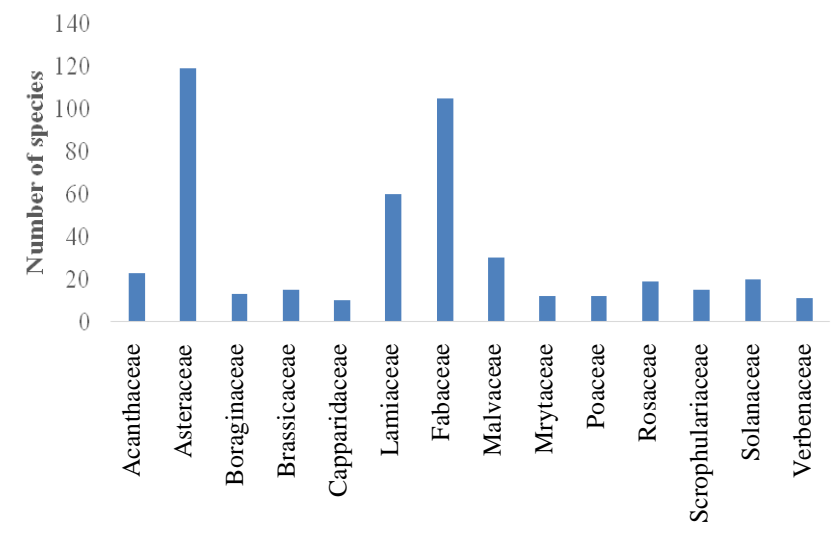

Figure 2. Number of bee flora species in major plant families in Ethiopia

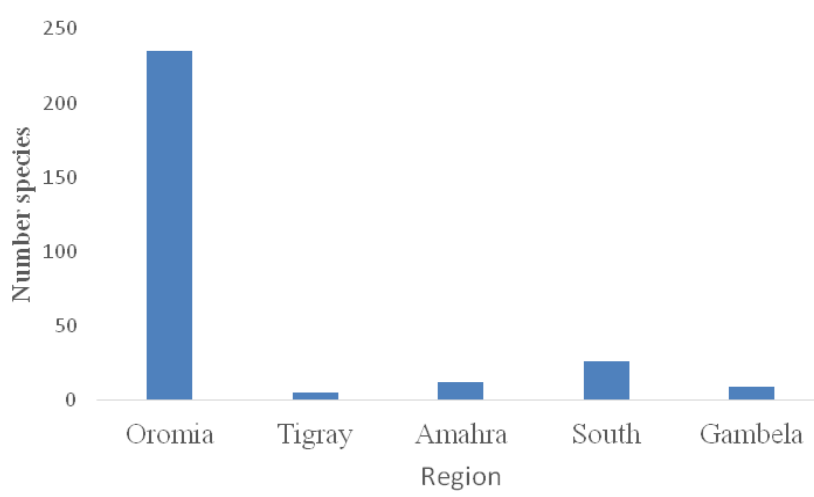

Figure 3. Distribution of bee forage in regional states of Ethiopia

Table 2. Bee forage diversity in different floristic regions of Ethiopia

\begin{tabular}{lccc}
\hline Floristic region & Richness & H'$^{\prime}$ & Evenness \\
\hline SNNP & 89 & 3.7 & 0.82 \\
Oromia & 99.3 & 3.9 & 0.85 \\
Amhara & 79 & 3.8 & 0.87 \\
Tigray & 29.2 & 2.9 & 0.8 \\
BeneshangulGumuz & 60.3 & 3.6 & 0.89 \\
Gambella & 50.2 & 1.93 & 0.81 \\
& & & \\
\hline
\end{tabular}

Table 4. t-Test comparison and ANOVA for species diversity and species richness and evenness

\begin{tabular}{|c|c|c|c|c|c|}
\hline Factors & $\begin{array}{c}\text { Beekeeper home } \\
\text { gardens }\end{array}$ & $\begin{array}{c}\text { Non-beekeeper home } \\
\text { gardens }\end{array}$ & t-Test & ANOVA & $\begin{array}{c}\text { Mann-Whitney } \\
\text { U test }\end{array}$ \\
\hline Shannon species diversity & $2.05 \pm 0.08$ & $1.40 \pm 0.06$ & $* * *$ & $* * *$ & \\
\hline Evenness & $0.87 \pm 0.03$ & $0.79 \pm 0.03$ & N.S. & N.S. & \\
\hline Species richness & $12.58 \pm 0.81$ & $6.5 \pm 0.53$ & $* * *$ & $* * *$ & $* * *$ \\
\hline
\end{tabular}

Note: $* * *$ Highly significant at $(\mathrm{P}<0.001)$, N.S. - Not significantly different $(\mathrm{P}>0.05)$ (Source: Debissa, 2006)

Table 5. Types of plant species preferred for Galessa watershed management

\begin{tabular}{lllll}
\hline Plant species & Family & Local name & Habit & Other uses \\
\hline Urtica simensis & Urticaceae & Dobbi & Herb & Food \\
Buddleja polystachya & Buddlejaceae & Anfare & Shrub & Fuelwood \\
Chamaecytisus proliferus & Fabaceae & Treelucern & Shrub & Fodder and fuelwood \\
Dombeya torrida & Sterculiaceae & Dannisa & Tree & Fuelwood and fences \\
Eucalyptus globulus & Myrtaceae & Bargamo & Tree & Construction, fuelwood \\
Hagenia abyssinica & Rosaceae & Hexxo & Tree & Medicine and timber \\
Maesa lanceolata & Myrsinaceae & Abbayyi & Shrub & Fence and fuelwood \\
Solanecio gigas & Asteraceae & Osole & Shrub & Fences \\
Vernonia amygdalina & Asteraceae & Ebichaa & Shrub & Fuelwood and medicine \\
\hline Sound & & & &
\end{tabular}

Source: Tura et al. (2014b) 
The analysis of vegetation data using the Shannon Wiener diversity index using natural logarithm revealed that Oromia has the highest species diversity (3.97) followed by South nations and Nationalities People region, (3.7) Amhara (3.4) and Tigray (2.5) and Gambella (1.93) (Table 2). The species richness also varied significantly among the regions and the same pattern is followed for the species evenness.

\section{FLORAL CALENDAR OF BEE RESOURCES}

Floral calendar is a timetable that indicates the approximate date and duration of the blossoming periods of the important honey plants (Diver 2002; Tura and Admassu 2018a). Flowering calendars can be applied to various beekeeping management activities such as placing hives near to particular crops and deciding the best time for honey harvest or colony swarming. Hence, adequate knowledge about bee flora in association with floral calendar is the prerequisite in beekeeping (Bista and Shivakoti 2001; Tura and Admassu 2018a). Every region in Ethiopia has its own active and dearth periods of short or long duration depending on intensity of rainfall. The majority of bee plants flower after the heavy rainy season from July to September and most of the Ethiopian highlands are covered with golden-yellow flowers of Bidens spp., Guizotia spp. and Trifolium spp with many different colors (Fitchl and Admassu 1994; Tessega 2009; Tura and Admassu 2018a). Following the flowering period, the end of October and early November is the major honey flow period in central and northern parts of Ethiopia. On the other hand, in southwest and southeastern parts of Ethiopia, the major honey flow period occurs from MayJune (Admassu et al. 2017). There are also some minor honey flow periods during January and march from Vernonia amygdalina and Coffea arabica flowers (Tura and Admassu 2018a).

\section{BEE FORAGE PERFORMANCE EVALUATION}

An attempt of screening major bee forage source plants has been done on the most common herbaceous plants existing in highlands and mid altitudes of the rift valley regions of Ethiopia based on germination rate, number of flower heads per plant, foraging intensity of honeybees and duration of flowering (Tura et al. 2014a; Tura and Admassu 2018b). Accordingly, Guizotia scabra, Guizotia abyssinica, Brassica carinata, and Caylusea abyssinica are found more potential for highlands while Echium plantaginium, Becium grandiflorum, Melilotus alba, and Fagophyrum esculentum are more potential in semi-arid parts of Rift valley of central Ethiopia

\section{THE ROLE OF BEEKEEPING IN CONSERVING NATURAL FOREST, AGROFORESTRY AND BIODIVERSITY}

The significance of apiculture in agroforestry and vegetation conservation, as well as the contribution of apiculture in household livelihood improvement, have been reported (Debissa 2006). Accordingly, the majority of the beekeeper households $(83.9 \%)$ are growing and conserving plants for their honeybees and other economic uses. Beekeepers have maintained higher plants diversity as compare to non-beekeepers (Table 4). As the result of the introduction of beekeeping technology with forest conservation at Menagesha Subaforest, beekeepers increased the yield of honey by four folds $(411 \%)$ and the revenue increased by 5.76 folds $(576 \%$ ) (Admassu et al. 2014b). Therefore, integration of beekeeping technology with conservation of forests will enhance the income of household and encourage planting of bee forages which directly contributes for sustainable forest management.

In most cases, success in beekeeping depends on the availability of sufficient bee forage in terms of both quality and quantity. Hence, beekeeping is more dependent on the existing ecological conditions of an area than any other livestock activity. In areas, where beekeeping is not suitable, other improved management skills and advanced technologies alone cannot make beekeeping successful. Thus a number of interventions have been made in country to restore degraded areas to protect from massive soil erosion to increase the productivity of ecosystem including apicultural production. For instance, bee forage developments and rehabilitation in degraded areas through reclamation and enclosure approach in northern Ethiopia can be mentioned as best practice for conservation of natural resources which improves appropriate conditions for apiculture. In view of this, an attempt has been made to assess the role of beekeeping in watershed conservation around the Galessa watershed area with active involvement of the community (Tura et al. 2014) resulted in two-fold increase in bee forage as listed in Table 5.

\section{CONCLUSION AND RECOMMENDATION}

This review indicated that Ethiopia is rich in botanical diversity for beekeeping. However, most of the identifications are limited to central highlands and from western Ethiopia. Thus, further collection and documentation of bee flora are required in unaddressed areas of the country. In addition to this, distribution of major bee forage species needed to be mapped and protected for sustainable honey production and evaluation of the carrying capacity of agro-ecosystem for honey production. Furthermore, the integration of beekeeping with watershed management has brought impact on the livelihood of the community through income generation and planting of trees and shrubs for honey production. Thus, we recommend to scaling up of integration of beekeeping technologies with natural resource conservation 
is important to conserve the biodiversity of Ethiopia, other bees, plants and animals.

\section{ACKNOWLEDGEMENTS}

We would like to acknowledge all the previous investigators who produced valuable research articles for the analysis of review.

\section{REFERENCES}

Admassu A, Kibebew W, Amssalu B, Ensermu K. 2014a. Honeybee Forages of Ethiopia. United Printers, Addis Ababa.

Admassu A, Kibebew W, Tura B. 2014b. Case study on contribution of beekeeping to the income generation of the households bordering Menagesha Suba State Forest. http://www.apitradeafrica.org/Documents/Technical Papers

Bista S, Shivakoti PG. 2001. Honeybee flora at Kabre Dolakha District, Nepal. J Nepal Agric Res 4 (5): 16-25. DOI: 10.3126/narj.v4i0.4859

Central Statistics Agency (CSA). 2017. Federal Democratic Republic of Ethiopia report on: Livestock and livestock characteristics, Addis Ababa.

Debissa L. 2006. The Role Apiculture in Vegetation Characterization and Household Livelihood in Walmaraa District, Central Ethiopia. [M.Sc Thesis]. Debub University Wondo Genet College of Forestry Awassa Ethiopia.

Diver S. 2002. Phenology web links: (1) sequence of bloom, floral calendars, what's in bloom; (2) birds, bees, insects and weeds. National Sustainable Agriculture Information Service - ATTRA, United States.

Ensermu K, Sebsebe D. 2014. Diversity of vascular plant taxa of the flora of Ethiopia and Eritrea. Ethiop J Biol Sci 13: 37-45.

Fitchl R, Admassu A. 1994. Honeybee Flora of Ethiopia. Margraf Verlag, Germany.

Friis Ib, Sebsebe D, Van Bruegel P. 2012. Atlas of the Potential Vegetation of Ethiopia. The Royal Danish Academy of Science and Letters, Denmark.
Gemechis LY. 2014. Review of Progress in Ethiopian Honey Production and Marketing. Holeta Bee Research Center (HBRC), Holeta.

Gidey Y, Mekonen T. 2010. Participatory technology and constraints assessment to improve the livelihood of beekeepers in Tigray Region, Northern Ethiopia. CNCS Mekelle University 2 (1): 76-92. DOI: 10.4314/mejs.v2i1.49654

Paulos D. 2011. Ethiopian Honey: Accessing International Markets with Inclusive Business and Sector Development. SNV, Post Implementation Review Report, November

Tessega B. 2009. Honeybee production and marketing systems, constraints and opportunities in Burie District of Amhara Region, Ethiopia. [M.Sc. Thesis]. Bahir Dar University, Ethiopia.

Tura B, Admassu A, Kibebew W. 2017. Screening of potential shrubs for bee forage development. J Plant Sci 5 (5): 160-164.

Tura B, Admassu A. 2018a. Honeybee flora resources of Guji Zone, Ethiopia. J Biol Agric Healthcare 8 (21): 1-9.

Tura B, Admassu A. 2018b. Performance evaluation of herbaceous of bee forages for semi-arid parts of the rift valley of central, Ethiopia. Adv Plants Agric Res 8 (5): 389-392. DOI: 10.15406/apar.2018.08.00342

Tura B. 2018. Lowland semi-evergreen forest of Ethiopia. For Res Eng Int J 2 (5): 244-248.

Tura BK, Admassu AM, Kibebew WH. 2014a. Investigating the role of apiculture in watershed management and income improvement in Galessa protected area, Ethiopia. Agric For Fish 3 (5): 380-385. DOI: 10.11648/j.aff.20140305.18

Tura BK, Admassu AM, Kibebew WH. 2014b. Screening of potential herbaceous honey plants for beekeeping development. Agric For Fish 3 (5): 386-391. DOI: 10.11648/j.aff.20140305.18

USAID (United States Agency for International Development). 2012. Agricultural Growth Program-Agribusiness and Market Development (AGP-AMDe) Project. Submitted by ACDI/VOCA to Contracting Officer's Representative Tewodros Yeshiwork, USAID Ethiopia.

Zerihun W. 2012. Ecological and Environmental Data Analysis: Basics, Concepts and Methods. Lambert Academic Publishing, Deutschland, Germany.

Zewdu A, Desalegn B, Amssalu B, Gebreamlak B, Tolera K. 2016. Assessment of alien honeybee species (Apis florea) in North West and Northern Ethiopia. Greener J Agri Sci 6 (3): 93-101. DOI: 10.15580/GJAS.2016.3.012016019 